\title{
Mononuclear Tungsten(VI) Phenylimido Phenoxide and Alkoxide Complexes with Intramolecular Amine Coordination: Molecular Structure of $\mathrm{WCl}_{3}(=\mathrm{NPh})\left[\mathrm{OC}_{6} \mathrm{H}_{2}\left(\mathrm{CH}_{2} \mathrm{NMe}_{2}\right)_{2}-2,6-\mathrm{Me}-4\right]$
}

\author{
Paul A. van der Schanf, ${ }^{\dagger}$ Jaap Boersma, ${ }^{\dagger}$ Wilbert J. J. Smeets, ${ }^{\ddagger}$ Anthony L. Spek, ${ }^{\ddagger}$ and \\ Gerard van Koten", \\ Debye Institute, Department of Metal-Mediated Synthesis, and Bijvoet Center for \\ Biomolecular Research, Laboratory of Crystal and Structural Chemistry, Utrecht University, \\ Padualaan 8, $3584 \mathrm{CH}$ Utrecht, The Netherlands
}

Received March 3, $1993^{\circ}$

\begin{abstract}
Mononuclear tungsten(VI) phenylimido phenoxide and alkoxide chlorides have been synthesized in which a potential intramolecularly coordinating amine donor atom is present. The selected ligands were phenoxides with one or two ortho-(dimethylamino)methyl groups, $\left[\mathrm{OC}_{6} \mathrm{H}_{4} \mathrm{CH}_{2} \mathrm{NMe}_{2}-2\right]$ (a) and $\left[\mathrm{OC}_{6} \mathrm{H}_{2}\left(\mathrm{CH}_{2} \mathrm{NMe}_{2}\right)_{2}-2,6-\mathrm{Me}-4\right]$ (b), respectively, 8-quinolinolate (8-quin) (c) or $\alpha$-substituted 2-pyridylmethoxides, i.e. 2,4-dimethyl-3-(2-pyridyl)-3-pentoxide (d) and diphenyl-2-pyridylmethoxide (e), respectively. They were attached to the metal center by reaction of their lithium or sodium salts with $\mathrm{WCl}_{4}(=\mathrm{NPh})\left(\mathrm{OEt}_{2}\right)$ in diethyl ether. To establish the influence of a potentially intramolecular coordinating amine function, three methyl-substituted phenoxide complexes have been prepared in which a diethyl ether molecule instead of the tertiary amine function coordinates to tungsten. Variable-temperature NMR spectroscopy as well as cryoscopic molecular weight measurements in benzene indicate that these complexes are six-coordinate monomers in solution. The solid-state structure of $\mathrm{WCl}_{3}(=\mathrm{NPh})\left[\mathrm{OC}_{6} \mathrm{H}_{2}\left(\mathrm{CH}_{2} \mathrm{NMe}_{2}\right)_{2}-2,6\right.$ $\mathrm{Me}-4]$ (2a), a tungsten(VI) phenylimido phenoxide containing two potentially ortho-chelating (dimethylamino)methyl groups, has been determined. Crystals of $2 a$ are monoclinic, space-group $P 21 / c$, with unit-cell dimensions $a=6.893(1) \AA, b=15.415(2) \AA, c=21.334(2) \AA, \beta=94.53(1)^{\circ}$, and $V=2259.7 \AA^{3}, Z=4, R=0.0353$, and $\boldsymbol{R}_{\mathrm{w}}=0.0259$ for 3544 observed reflections and 260 parameters. One of the ortho- $\mathrm{CH}_{2} \mathrm{NMe}_{2}$ substituents of the "pincer-phenolate" ligand intramolecularly coordinates to the tungsten center trans to the phenylimido group, whereas the second ortho- $\mathrm{CH}_{2} \mathrm{NMe}_{2}$ group is not coordinated. This octahedral geometry was also found for $2 \mathrm{a}$ in solution, and even at elevated temperatures two resonance patterns were observed for two different ortho- $\mathrm{CH}_{2} \mathrm{NMe}_{2}$ substituents indicating that intramolecular exchange between the tertiary amine groups does not occur.
\end{abstract}

\section{Introduction}

During the last decade, tungsten(VI) phenoxides of the type $\mathrm{WCl}_{6-x}(\mathrm{OAr})_{x}(x=0-4,6)$ or $\mathrm{W}(\mathrm{O}) \mathrm{Cl}_{4-y}(\mathrm{OAr})_{y},(y=0-4)$ have been reported. They are known to be very active metathesis catalysts for linear as well as cyclic olefins. These complexes require the addition of a cocatalyst, e.g. $\mathrm{R}_{x} \mathrm{AlCl}_{3-x}$ or an alkyltin hydride, to generate the active catalyst species in situ. ${ }^{1-9}$ The phenoxide groups present in these tungsten catalysts increase the solubility and stability of the complexes, and more importantly, they are used to influence the steric and electronic properties of the reaction site.

Intramolecular amine coordination in high-valent (arylamine)tungsten(VI) complexes greatly enhances their thermal stability. ${ }^{10}$ For example, a solution of the aryltungsten(VI) oxo complex $\mathrm{W}\left[(R)-\mathrm{C}_{6} \mathrm{H}_{4} \mathrm{CH}(\mathrm{Me}) \mathrm{NMe}_{2}-2\right] \mathrm{Cl}_{3}(=\mathrm{O})$ (see $\mathrm{i}$ in Figure 1),

- To whom correspondence should be addressed.

Debye Research Institute.

Bijvot Center for Biomolecular Research.

- Abstract published in Advance ACS Abstracts, October 1, 1993

(1) (a) Calderon, N.; Lawrence, J. P.; Ofstead, E. A. Adv. Organomet. Chem. 1979, 17, 449. (b) Ivin, K. J. Olefin Metathesis; Academic: London, 1983.

(2) Dragutan V.; et al. Olefin Metathesis and Ring-Opening Polymerization of Cyclo-Olefins; Wiley-Interscience: New York, 1985.

(3) (a) Dodd, H. T.; Rut, K. J. J. Mol. Catal. 1982, 15, 103. (b) Dodd, H. T.; Rut, K. J. J. Mol. Catal. 1985, 28, 33.

(4) Quignard, F.; Leconte, M.; Basset, J. M. J. Mol. Catal. 1985, 28, 27.

(5) Bell, A. Polym. Prepr. (Am. Chem. Soc., Div. Polym. Chem.) 1991, 64, 102; 1992, 67, 39.

(6) Bell, A. J. Mol. Catal. 1992, 76, 165

(7) Sjardijn, W.; Kamer, A. H. U.S. Patents 4,729,976, 1986, and 4,810, 762,1987

(8) Kolodziej, R. M.; Schrock, R. R.; Dewan, J. C. Inorg. Chem. 1988, 28, 1243.

(9) Beshouri, S. M.; Rothwell, I. P. Inorg. Chem. 1986, 25, 1962.

(10) Van der Schaaf, P. A.; Boersma, J.; Kooijman, H.; Spek, A. L.; Van Koten, G. Organometallics, in press.

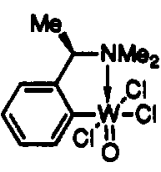

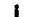

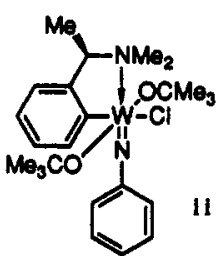

Figure 1. Examples of aryltungsten(VI) complexes stabilized by intramolecular amine coordination.

containing a chelating arylamine ligand, is stable up to at least $120^{\circ} \mathrm{C}$ in an inert atmosphere. In addition, W $\left[(R)-\mathrm{C}_{6} \mathrm{H}_{4} \mathrm{CH}\right.$ $\left.(\mathrm{Me}) \mathrm{NMe}_{2}-2\right] \mathrm{Cl}(=\mathrm{NPh})\left(\mathrm{OCMe}_{3}\right)_{2}$ (ii in Figure 1), an aryltungsten(VI) phenylimido complex which contains also two $\pi$-electron-donating tert-butoxide anions, can be melted in air (mp $138^{\circ} \mathrm{C}$ ) without decomposition.

Recently, we reported the synthesis of the novel tungsten(VI) alkylidene complex $\mathrm{W}\left(\mathrm{C}_{6} \mathrm{H}_{4} \mathrm{CH}_{2} \mathrm{NMe}_{2}-2\right)\left(=\mathrm{CHSiMe} \mathrm{CH}_{3}\right)\left(\mathrm{CH}_{2}\right.$ $\left.\mathrm{SiMe}_{3}\right)(=\mathrm{NPh})$ and its reactivity toward linear and cyclic olefins, ketones, and aldehydes. ${ }^{11}$ The reactivity of this type of complex can be further tuned by the introduction of alkoxide or phenoxide ligands. ${ }^{12-19}$ Because of the electronic flexibility of these ligands

(11) Van der Schasf, P. A.; Smeets, W. J. J.; Spek, A. L.; Van Koten, G. J. Chem. Soc., Chem. Commun. 1992, 717.

(12) Bradley, D.C.; Mehrotra, R. C.; Gaur, D. P. Metal Alkoxides; Academic Press: London, 1978.

(13) Kress, J.; Wescek, M. Osborn, J. A. J Chem, Soc, Chem. Commun 1982, 514. (b) Aguero, A.; Kress, J.; Osborn, J. A. J. Chem. Soc., Chem. Commun. 1985, 793.

(14) Kress, J.; Aguero, A.; Osborn, J. A. J. Mol. Catal. 1986, 36, 1.

(15) Freudenberger, J. H.; Schrock, R. R. Organometallics 1985, 4, 1937.

(16) Pederson, S. F.; Schrock, R. R. J. Am. Chem. Soc. $1982,104,7483$.

(17) Schrock, R. R. J. Organomet. Chem. 1986, 300, 249.

(18) Schaverien, C. J.; Dewan, J. C.; Schrock, R. R. J. Am. Chem. Soc. 1986, $108,2771$.

(C) 1993 American Chemical Society 
<smiles>COc1ccccc1CN(C)C</smiles><smiles>COc1c(CN)cc([N+](=O)[O-])cc1CN</smiles>

b

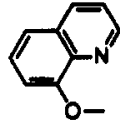

c

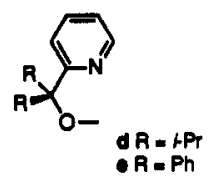

Figure 2. Selected alkoxide and phenoxide ligands with a potentially ortho-chelating amine donor.

Scheme I. Synthesis of Complexes 1-5a

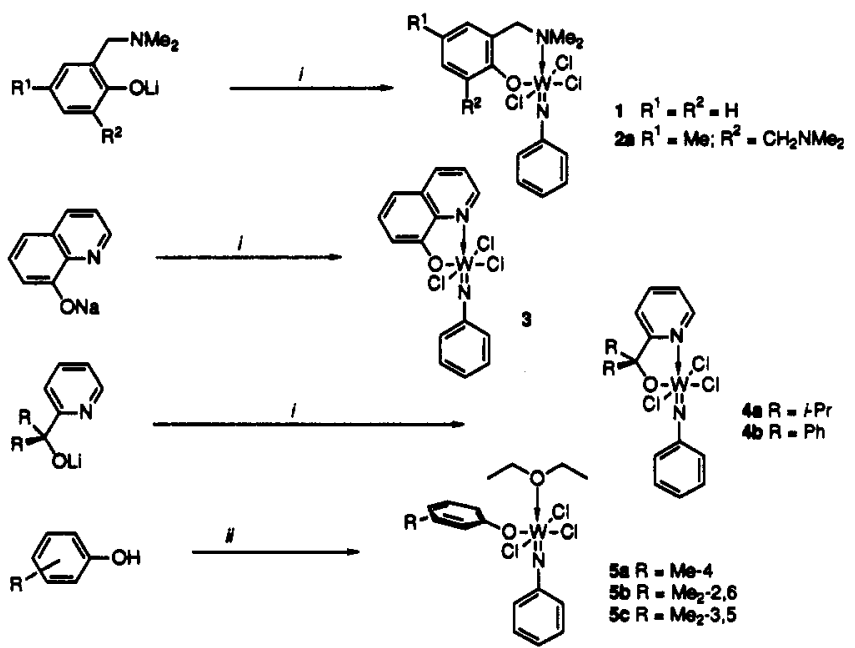

- Key: (i) Ligands added as their lithium or sodium salts to $\mathrm{WCl}_{4}(-\mathrm{NPh})\left(\mathrm{OEt}_{2}\right)$, in $\mathrm{Et}_{2} \mathrm{O}$ at $0^{\circ} \mathrm{C}$; yields 86-92\%; (ii) via alcoholysis, in $\mathrm{Et}_{2} \mathrm{O}$; yields $85-95 \%$.

the degree of $\pi$-donation can be continuously adapted to the need of the metal atom, in particular during a reaction. An obvious next step is to combine intramolecular amine coordination with phenoxide and alkoxide ligands, leading to the preparation of mononuclear tungsten(VI) alkylidene complexes containing an intramolecularly coordinating alkoxide or phenoxide ligand. To this end, we started with the preparation and characterization of a series of tungsten(VI) phenylimido phenoxide and alkoxide chlorides containing a potentially coordinating amine donor. These complexes have been prepared to gather information about the stability of these complexes and their reactivity, for example toward intramolecular $\mathrm{C}-\mathrm{H}$ activation, and to investigate their use as starting compounds for the synthesis of active tungsten(VI) alkylidene species.

The ligands we used, depicted in Figure 2, are all monoanionic $O, N$-chelating ligands. The phenoxide ligands (a, b) will form a six-membered chelate ring upon $\mathrm{W}-\mathrm{N}$ coordination, while the 8-quinolinolate (8-quin) (c) and 2-pyridylmethoxide ligands (d, e) will form a five-membered chelate ring. The "pincer-phenolate" ligand (b) differs from the other ligands because of the presence of two potentially ortho-chelating amine substituents.

To establish the influence of intramolecular $\mathrm{W}-\mathrm{N}$ coordination on the stability and reactivity of these tungsten(VI) species, three substituted phenoxide (4-methyl-, 2,6-dimethyl-, and 3,5-dimethyl) tungsten(VI) phenylimido chlorides were prepared in which such a donor possibility is absent. In these complexes, the remaining sixth coordination site is occupied by a coordinating $\mathrm{Et}_{2} \mathrm{O}$ molecule.

\section{Results}

Synthesis of the Complexes. The complexes $1-4$ were prepared by reacting $\mathrm{WCl}_{4}(-\mathrm{NPh})\left(\mathrm{OEt}_{2}\right)$ with the lithium or sodium salts of the phenoxide, alkoxide, or 8-quinolinolate ligands (see Scheme I). The methyl-substituted phenoxide complexes, 5a-c, were prepared via direct alcoholysis of $\mathrm{WCl}_{4}(=\mathrm{NPh})\left(\mathrm{OEt}_{2}\right)$ by the corresponding methyl-substituted phenols.

(19) Buhro, W. E.; Chisholm, M. H. Adv. Organomet. Chem. 1987, $27,311$.
Scheme II. Synthesis of $\mathbf{2 a}, \mathbf{b}^{a}$

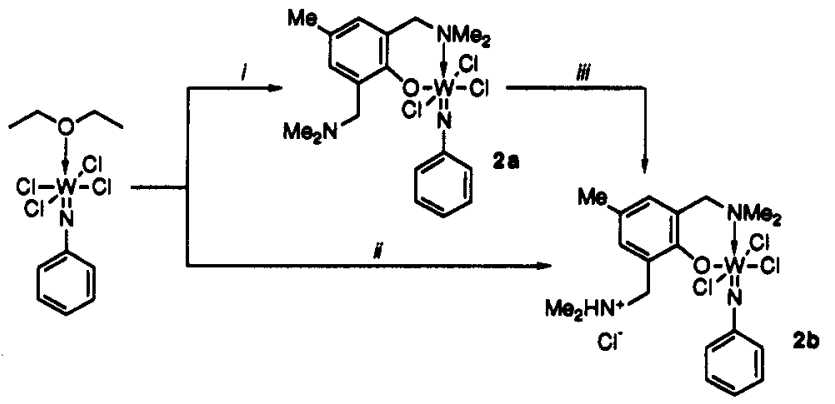

a Reaction in $\mathrm{Et}_{2} \mathrm{O}$. Key: (i) Addition of lithium phenoxide or via an alcoholysis reaction in the presence of $\mathrm{NEt}_{3}$; (ii) alcoholysis reaction without $\mathrm{NEt}_{3}$; (iii) 1:1 molar reaction with $1.5 \mathrm{M} \mathrm{HCl}$ solution in $\mathrm{Et}_{2} \mathrm{O}$.

The latter route is also a good alternative for the preparation of $2 \mathrm{a}$, provided that a nonnucleophilic base, such as triethylamine, is present to bind the $\mathrm{HCl}$ formed during the reaction. When this base is not added, the second ortho- $\mathrm{CH}_{2} \mathrm{NMe}_{2}$ substituent of the "pincer-phenolate" acts as the base and the $\mathrm{HCl}$ salt $2 \mathrm{~b}$ is obtained; see Scheme II.

These new complexes are intensely colored; e.g., the aryloxides, $1,2 a, 3$, and $5 \mathrm{a}-\mathrm{c}$, are deep-purple or black solids which gave deep-purple colored solutions (benzene), whereas the alkoxides, $4 a, b$, are deep red, both as solids and in solution. The solid complexes are moisture sensitive but can be handled for short periods ( $<1 \mathrm{~min}$ ) in air and can be stored for longer periods in an inert atmosphere.

In contrast with $\mathbf{2 a}$, complex $\mathbf{2 b}$, with one protonated ortho$\mathrm{CH}_{2} \mathrm{NMe}_{2}$ substituent, is insoluble in aromatic solvents, such as toluene, and hydrocarbons and only slightly soluble in dichloromethane. Complex $\mathbf{2 b}$ undergoes quantitative metathesis with, for example, acetone in a Wittig-type reaction to produce an $N$-phenyl imine and the corresponding tungsten(VI) oxo derivative (eq 1). Unfortunately, attempts to isolate the newly formed tungsten oxo phenoxide complexes were unsuccessful.

$L_{n} M=N-P h+\mathrm{Me}_{2} \mathrm{CO} \longrightarrow \mathrm{Me}_{2} \mathrm{C}=\mathrm{N}-\mathrm{N}_{-} \mathrm{Ph}+\mathrm{L}_{\mathrm{M}} \mathrm{O}$

Solid-State structure of $2 \mathbf{a}$. In order to establish the proposed $O, N$-bidentate bonding of the "pincer-phenolate" ligand in $2 \mathrm{a}$, its solid-state structure was determined by $\mathrm{X}$-ray diffraction. The unit cell of $2 \mathrm{a}$ comprises the packing of four discrete molecules. An ORTEP plot is given in Figure 3. The atomic coordinates and the selected bond distances and angles are given in Tables I and II, respectively.

The tungsten center has a slightly distorted octahedral geometry, due to intramolecular coordination of the orthochelating $\mathrm{CH}_{2} \mathrm{NMe}_{2}$ group, which occupies an axial position. This $\mathrm{NMe}_{2}$ group is bonded trans to the phenylimido group, whereas the phenoxide oxygen and the three remaining chloride atoms are in equatorial positions. The second ortho-(dimethylamino)methyl group is not coordinated to the metal center and is in a position that minimizes steric interaction with the other ligands. The $\mathrm{W}-\mathrm{O}-\mathrm{C}_{3}-\mathrm{N}$ six-membered chelate ring is puckered. The W-N(1) bond length of 2.451 (4) $A$ is comparable with those found for tertiary amine dative bonds in tungsten(VI) ${ }^{11}$ and tantalum(V) complexes. ${ }^{20}$ As expected, the length of this bond by a tertiary amino group is significantly longer than lengths of those reported for aromatic heterocyclic sp2-nitrogen dative bonds. For example, comparable tungsten complexes containing 8-quin-

(20) (a) Abbenhuis, H. C. L.; Grove, D. M.; Van Mier, G. P. M.; Spek, A. L.; Van Koten, G. J. Chem. Soc., Chem. Commun. 1989, 1581. (b) Abbenhuis, H. C. L.; Grove, D. M.; Van der Sluis, P.; Spek, A. L.; Van Koten, G. Recl. Trav. Chim. Pays-Bas 1990, 109, 446. (c) Abbenhuis, H.C. L.; Feiken, N.; Haarman, H. F.; Grove, D. M.; Horn, E.; Kooijman, H.; Spek, A. L.; Van Koten, G. Angew. Chem., Int. Ed. Engl. 1991, 30, 996. 


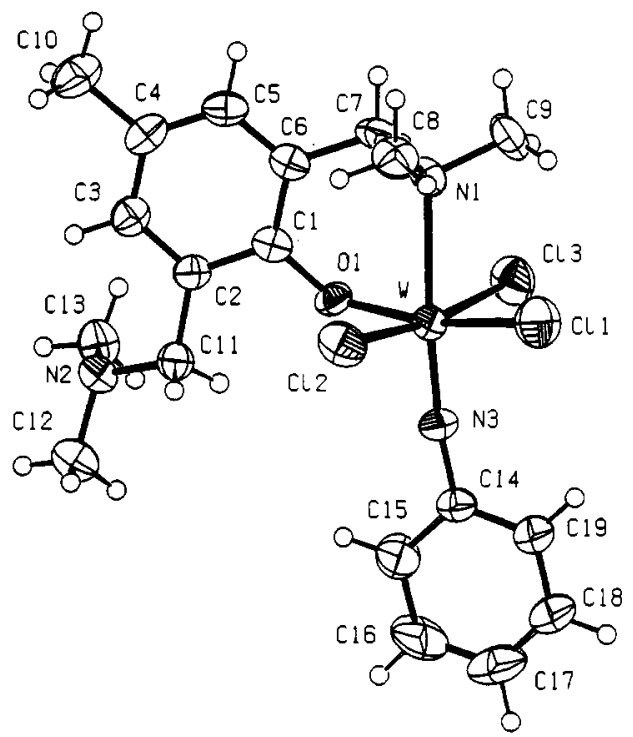

Figure 3. ORTEP drawing ( $50 \%$ probability level) of $\mathrm{WCl}_{3}$ $(=\mathrm{NPh})\left[\mathrm{OC}_{6} \mathrm{H}_{2}\left(\mathrm{CH}_{2} \mathrm{NMe}\right)_{2}-2,6-\mathrm{Me}-4\right]$ (2a), with the adopted numbering scheme.

Table I. Fractional Coordinates and Equivalent Isotropic Thermal Parameters for $\mathrm{WCl}_{3}(=\mathrm{NPh})\left[\mathrm{OC}_{6} \mathrm{H}_{2}\left(\mathrm{CH}_{2} \mathrm{NMe}\right)_{2}-2,6-\mathrm{Me}-4\right]$ (2a)

\begin{tabular}{lccll}
\hline atom & $x$ & $y$ & \multicolumn{1}{c}{$z$} & \multicolumn{1}{c}{$U_{\text {eq, }}{ }^{a} \AA^{2}$} \\
\hline $\mathrm{W}$ & $0.41822(3)$ & $0.07236(1)$ & $0.18508(1)$ & $0.0354(1)$ \\
$\mathrm{Cl}(1)$ & $0.6339(2)$ & $0.06391(10)$ & $0.10653(7)$ & $0.0698(6)$ \\
$\mathrm{Cl}(2)$ & $0.6189(2)$ & $-0.02972(9)$ & $0.24285(7)$ & $0.0570(5)$ \\
$\mathrm{Cl}(3)$ & $0.2496(2)$ & $0.18958(9)$ & $0.13599(7)$ & $0.0600(6)$ \\
$\mathrm{O}(1)$ & $0.3043(5)$ & $0.09013(19)$ & $0.26125(14)$ & $0.0366(11)$ \\
$\mathrm{N}(1)$ & $0.6413(6)$ & $0.1868(2)$ & $0.22543(18)$ & $0.0409(17)$ \\
$\mathrm{N}(2)$ & $0.0529(6)$ & $-0.0249(3)$ & $0.41239(18)$ & $0.0378(16)$ \\
$\mathrm{N}(3)$ & $0.2587(6)$ & $-0.0035(3)$ & $0.15136(18)$ & $0.0410(14)$ \\
$\mathrm{C}(1)$ & $0.3662(7)$ & $0.1149(3)$ & $0.3204(2)$ & $0.0337(17)$ \\
$\mathrm{C}(2)$ & $0.3046(7)$ & $0.0681(3)$ & $0.3707(2)$ & $0.0351(17)$ \\
$\mathrm{C}(3)$ & $0.3742(7)$ & $0.0933(3)$ & $0.4309(2)$ & $0.0415(17)$ \\
$\mathrm{C}(4)$ & $0.5003(8)$ & $0.1630(3)$ & $0.4417(2)$ & $0.0433(19)$ \\
$\mathrm{C}(5)$ & $0.5569(7)$ & $0.2087(3)$ & $0.3910(3)$ & $0.0431(19)$ \\
$\mathrm{C}(6)$ & $0.4920(7)$ & $0.1858(3)$ & $0.3298(2)$ & $0.0360(17)$ \\
$\mathrm{C}(7)$ & $0.5444(8)$ & $0.2383(3)$ & $0.2739(2)$ & $0.0440(19)$ \\
$\mathrm{C}(8)$ & $0.8287(7)$ & $0.1529(3)$ & $0.2542(3)$ & $0.051(2)$ \\
$\mathrm{C}(9)$ & $0.6906(10)$ & $0.2505(4)$ & $0.1769(3)$ & $0.064(3)$ \\
$\mathrm{C}(10)$ & $0.5708(9)$ & $0.1878(4)$ & $0.5086(2)$ & $0.062(2)$ \\
$\mathrm{C}(11)$ & $0.1691(7)$ & $-0.0082(3)$ & $0.3594(2)$ & $0.0400(17)$ \\
$\mathrm{C}(12)$ & $-0.0454(8)$ & $-0.1090(3)$ & $0.4057(3)$ & $0.055(2)$ \\
$\mathrm{C}(13)$ & $-0.0906(8)$ & $0.0427(3)$ & $0.4200(3)$ & $0.052(2)$ \\
$\mathrm{C}(14)$ & $0.1420(7)$ & $-0.0616(3)$ & $0.1166(2)$ & $0.0370(17)$ \\
$\mathrm{C}(15)$ & $0.0062(8)$ & $-0.1107(4)$ & $0.1454(3)$ & $0.059(2)$ \\
$\mathrm{C}(16)$ & $-0.1062(9)$ & $-0.1686(4)$ & $0.1081(3)$ & $0.082(3)$ \\
$\mathrm{C}(17)$ & $-0.0834(10)$ & $-0.1761(4)$ & $0.0449(3)$ & $0.079(3)$ \\
$\mathrm{C}(18)$ & $0.0480(10)$ & $-0.1276(4)$ & $0.0179(3)$ & $0.064(3)$ \\
$\mathrm{C}(19)$ & $0.1606(8)$ & $-0.0708(3)$ & $0.0528(2)$ & $0.0508(19)$ \\
& &
\end{tabular}

- $U(\mathrm{eq})=$ one-third of the trace of the orthogonalized $U$ tensor.

Table II. Selected Geometrical Parameters $\mathrm{WCl}_{3}(=\mathrm{NPh})\left[\mathrm{OC}_{6} \mathrm{H}_{2}\left(\mathrm{CH}_{2} \mathrm{NMe}\right)_{2}-2,6-\mathrm{Me}-4\right]$ (2a)

\begin{tabular}{llll}
\multicolumn{5}{c}{ Bond Lengths $(\AA)$} \\
W-N(1) & $2.451(4)$ & W-Cl(1) & $2.3299(15)$ \\
W-N(3) & $1.723(4)$ & W-Cl(2) & $2.3747(15)$ \\
W-O(1) & $1.880(3)$ & W-Cl(3) & $2.3496(15)$ \\
$\mathrm{C}(1)-\mathrm{O}(1)$ & $1.355(5)$ & $\mathrm{N}(3)-\mathrm{C}(14)$ & $1.380(6)$ \\
\multicolumn{5}{c}{} \\
W-N(3)-C(14) & \multicolumn{4}{c}{ Bond Angles (deg) } \\
Cl(1)-W-O(1) & $164.0(3)$ & $\mathrm{N}(1)-\mathrm{W}-\mathrm{N}(3)$ & $175.53(16)$ \\
$\mathrm{Cl}(2)-\mathrm{W}-\mathrm{Cl}(3)$ & $171.23(5)$ & $\mathrm{N}(1)-\mathrm{W}-\mathrm{O}(1)$ & $83.38(13)$ \\
& & $\mathrm{W}-\mathrm{O}(1)-\mathrm{C}(1)$ & $136.4(3)$
\end{tabular}

olinolate, or substituted derivatives, have $\mathrm{W}-\mathrm{N}$ bond lengths in the range of 2.188-2.290 $\AA .21-24$ The $W=N(3)$ bond length of $1.723(4) \AA$ and the $\mathrm{W}=\mathrm{N}(3)-\mathrm{C}(14)$ bond angle of $172.0(3)^{\circ}$

(21) Hanson, I. R.; Hughes, D. L. J. Chem. Soc., Dalton Trans. 1981, 390. are typical for arylimido ligands that are terminally bonded to electron-deficient early-transition-metal complexes. ${ }^{25}$ These small bond lengths and large bond angles are the result of a strong nitrogen to metal $\pi$-donation. ${ }^{25}$ The $\mathrm{W}-\mathrm{O}(1)$ bond length of $1.880(3) \AA$ is slightly longer than those in related tungsten(VI) phenoxides, e.g. cis- $\mathrm{WCl}_{4}\left(\mathrm{OC}_{6} \mathrm{H}_{3} \mathrm{Ph}_{2}-2,6\right)_{2}(1.824-1.855 \AA),{ }^{26,27}$ $\mathrm{WCl}_{3}\left(\mathrm{OC}_{6} \mathrm{H}_{3} i-\mathrm{Pr}_{2}-2,6\right)_{3}(1.832-1.845 \AA),{ }^{27}$ and trans-WCl$\left(\mathrm{OC}_{6} \mathrm{H}_{5}\right)_{4}{ }^{28}$ (average $\mathrm{W}-\mathrm{O}=1.82 \AA$ ).

Complexes in Solution. Association measurements in benzene show that $\mathrm{WCl}_{3}(=\mathrm{NPh})\left(\mathrm{OC}_{6} \mathrm{H}_{4} \mathrm{CH}_{2} \mathrm{NMe}_{2}-2\right)(1), \mathrm{WCl}_{3}$ $(=\mathrm{NPh})\left[\mathrm{OC}_{6} \mathrm{H}_{2}\left(\mathrm{CH}_{2} \mathrm{NMe}_{2}\right)_{2}-2,6-\mathrm{Me}-4\right]$ (2a), and $\mathrm{WCl}_{3}$ $(=\mathrm{NPh})\left[\mathrm{OC}-i-\mathrm{Pr}_{2}(2-\mathrm{Py})\right](4 \mathrm{a})$ are monomeric species in solution (see Experimental Section).

The NMR spectra of 1 and $2 a$ have comparable resonance patterns, indicating that the structures of these complexes in solution are related (see Table III and experimental data). Both complexes show broadened signals for the $\mathrm{NMe}_{2}$ and $\mathrm{CH}_{2} \mathrm{~N}$ hydrogens at ambient temperature, and in $2 \mathbf{a}$ the second (dimethylamino)methyl group appears as two sharp singlets, one for the $\mathrm{CH}_{2} \mathrm{~N}$ and one for the $\mathrm{NMe}_{2}$ hydrogens. This suggests that the structure of $2 a$ in solution is similar to that found in the solid state, i.e. a structure with one coordinating and one free (dimethylamino)methyl group (vide supra). Therefore, the single ortho- $\mathrm{CH}_{2} \mathrm{NMe}_{2}$ substituent in 1 most probably occupies the sixth coordination site, in analogy with the solid-state structure of $2 \mathrm{a}$. The broadened ${ }^{1} \mathrm{H}$ NMR signals for the $\mathrm{CH}_{2} \mathrm{NMe}_{2}$ hydrogens in complexes $\mathbf{1}$ and $\mathbf{2 a}$ at room temperature sharpen upon raising of the temperature to $80^{\circ} \mathrm{C}$. For $2 \mathrm{a}$, two sets of resonances remain for both ortho- $\mathrm{CH}_{2} \mathrm{NMe}_{2}$ substituents, indicating that also at elevated temperatures $\mathrm{W}-\mathrm{N}$ coordination is rigid on the NMR time scale and, moreover, that intramolecular exchange between ortho- $\mathrm{CH}_{2} \mathrm{NMe}_{2}$ substituents does not occur. Lowering the temperature to $-40^{\circ} \mathrm{C}$ gives rise to decoalescence of the broadened signals observed at room temperature: the $\mathrm{CH}_{2} \mathrm{~N}$ hydrogens appear as an AB-pattern, while two distinct singlets were observed for the $\mathrm{NMe}_{2}$ methyl groups. It must be noted that both 1 and $2 a$ have a molecular symmetry plane containing the phenoxide ligand. This implies that the observed diastereotopicity of the $\mathrm{CH}_{2} \mathrm{~N}$ hydrogens and the $\mathrm{NMe}_{2}$ methyl groups must arise from a different cause, i.e. the puckering of the sixmembered $\mathrm{W}-\mathrm{O}-\mathrm{C}_{3}-\mathrm{N}$ chelate ring in which the three carbon atoms are in one plane (see molecular structure of $2 a$ ). When inversion of the puckered conformation becomes slow on the NMR time scale, the apparent molecular symmetry plane disappears. The puckered conformation then is a stereogenic element which renders the $\mathrm{CH}_{2} \mathrm{~N}$ hydrogens and the $\mathrm{NMe}_{2}$ methyl groups diastereotopic. An example of such a process has been found in, for example, triorganotin halides containing a six-membered chelate ring. ${ }^{29}$ Figure 5 shows the two ring conformers, $\delta$ and $\lambda$, in 1, which are in fast exchange at ambient temperature. Upon lowering of the temperature, this ring-flipping process is slowed down until finally the slow-exchange limit is reached $\left(\Delta G^{*} \approx 47\right.$ $\mathrm{kJ} \mathrm{mol}^{-1}$ for both 1 and $\mathbf{2 a}$ ).

It is more difficult to deduct the structure of the complexes $\mathrm{WCl}_{3}(=\mathrm{NPh})$ (8-quin) (3) and $\mathrm{WCl}_{3}(=\mathrm{NPh})\left[\mathrm{OR}_{2}\right.$ (2-Py)] (R

(22) Chatt, J.; Fakley, M. E.; Richards, R. L.; Hanson, I. R.; Hughes, D. L. J. Organomet. Chem. 1979, 170, C6.

(23) Day, R. O.; Batschelet, W. H.; Archer, R. D. Inorg. Chem. 1980, 19, 2113

(24) Bonds, W. D.; Archer, R. D.; Hamilton, W. C. Inorg. Chem. 1971, 10, 1764

(25) For reviews on imido complexes see: (a) Nugent, W. A.; Haymore, B. L. Coord. Chem. Rev. 1980, 31, 123-175. (b) Cenini, S.; LaMonica, G. Inorg. Chim. Acta 1976, 18, 279. (c) Nugent, W. A.; Mayer, J. M. Metal-Ligand Multiple Bonds; Wiley-Interscience: New York, 1988.

(26) Kerschner, J. L.; Fanwick, P. E.; Rothwell, I. P.; Huffman, J. C. Inorg. Chem. 1989, 28, 780.

(27) Quignard, F.; Leconte, M.; Basset, J.-M.; Hsu, L.-Y.; Alexander, J. J.; Shorte, S. G. Inorg. Chem. 1987; 26, 4272.

(28) Handy, L. B.; Fair, C. K. Inorg. Nucl. Chem. Lett. 1975, 11, 496.

(29) Van Koten, G.; Jastrzebski, J. T. B. H.; Noltes, J. G.; Verhoeckx, G. J.; Spek, A. L.; Kroon, J. J. Chem. Soc., Dalton Trans. 1980, 1352. 
Table III. Selected ${ }^{1} \mathrm{H}$ and ${ }^{13} \mathrm{C}$ NMR Data for the Tungsten(IV) Complexes 1-5o

\begin{tabular}{|c|c|c|c|c|}
\hline no. & complex & $C_{\text {lpso }}-0$ & $C_{\text {ipeo }}-\mathrm{NPh}$ & $p-H \mathrm{NPh}$ \\
\hline $\begin{array}{l}1 \\
2 a \\
3 \\
4 a \\
4 b \\
5 a \\
5 b \\
5 c\end{array}$ & $\begin{array}{l}\mathrm{WCl}_{3}(=\mathrm{NPh})\left(\mathrm{OC}_{6} \mathrm{H}_{4} \mathrm{CH}_{2} \mathrm{NMe}_{2}-2\right) \\
\mathrm{WCl}_{3}(=\mathrm{NPh})\left(\mathrm{OC}_{6} \mathrm{H}_{2}\left(\mathrm{CH}_{2} \mathrm{NMe}_{2}\right)_{2}-2,6-\mathrm{Me}-4\right] \\
\mathrm{WCl}_{3}(=\mathrm{NPh})\left(8-\mathrm{Nuinolinolate}^{b}\right. \\
\mathrm{WCl}_{3}(=\mathrm{NPh})\left[\mathrm{OC} i-\mathrm{Pr}_{2}([2]-\mathrm{Py})\right] \\
\mathrm{WCl}_{3}(=\mathrm{NPh})\left[\mathrm{OCPh}_{2}([2]-\mathrm{Py})\right] \\
\mathrm{WCl}_{3}(=\mathrm{NPh})\left(\mathrm{OC}_{6} \mathrm{H}_{4} \mathrm{Me}-4\right)\left(\mathrm{OEt}_{2}\right) \\
\mathrm{WCl}_{3}(=\mathrm{NPh})\left(\mathrm{OC}_{6} \mathrm{H}_{3} \mathrm{Me}_{2}-2,6\right)\left(\mathrm{OEt}_{2}\right) \\
\mathrm{WCl}_{3}(=\mathrm{NPh})\left(\mathrm{OC}_{6} \mathrm{H}_{3} \mathrm{Me}_{2}-3,5\right)\left(\mathrm{OEt}_{2}\right)\end{array}$ & $\begin{array}{l}160.5 \\
157.4 \\
158.6 \\
168.3 \\
164.7 \\
163.6 \\
163.7 \\
165.6\end{array}$ & $\begin{array}{l}151.3 \\
151.6 \\
149.4 \\
151.5 \\
151.2 \\
150.8 \\
151.1 \\
150.8\end{array}$ & $\begin{array}{l}6.36 \\
6.47 \\
7.12 \\
6.48 \\
6.44 \\
6.38 \\
6.36 \\
6.36\end{array}$ \\
\hline
\end{tabular}

a All values are in $\delta$ relative to $\mathrm{SiMe}_{4}$; benzene- $d_{6}$ solvent, at $300 \mathrm{~K} .{ }^{b}$ In chloroform- $d_{1}$.
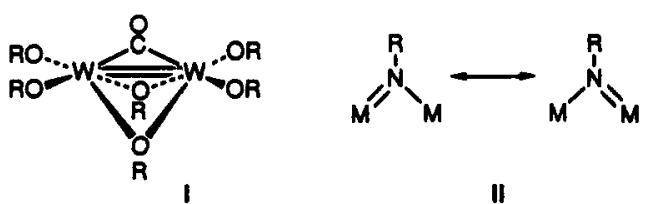

III

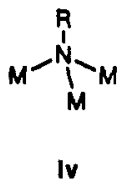

Figure 4. Schematic representation of examples of bridging alkoxide and imido ligands in early-transition-metal complexes.

$=i$ - $\mathrm{Pr}, 4 \mathrm{a} ; \mathrm{R}=\mathrm{Ph}, \mathbf{4 b}$ ) from their NMR data, since stereogenic elements are absent. However, the chemical shift of the proton at the ortho- $\mathrm{C}$ in the heterocyclic ring ( $\mathrm{H}^{2}$ for 8 -quin and $\mathrm{H}^{6}$ for the pyridine groups) can be used as a very efficient indicator for the absence or presence of $\mathrm{W}-\mathrm{N}$ coordination. In the latter case this hydrogen atom is forced into the proximity of a WVL-halogen bond and a typical downfield shift is observed. For complexes 3 and $4 a, b$ these chemical shift differences are $1.19,1.34$, and $1.33 \mathrm{ppm}$, respectively, with respect to the chemical shift of the corresponding hydrogen atom in the free ligand (alcohols). These shift differences indicate that $\mathrm{W}-\mathrm{N}$ coordination occurs and that, consequently, the W-center in 3 and $\mathbf{4 a , b}$ is six-coordinated as a result of intramolecular coordination of the amino group.

The NMR data of $\mathrm{WCl}_{3}(=\mathrm{NPh})(\mathrm{OAr})\left(\mathrm{OEt}_{2}\right)(\mathrm{OAr}=$ $\mathrm{OC}_{6} \mathrm{H}_{4} \mathrm{Me}-4$ (5a), $\mathrm{OC}_{6} \mathrm{H}_{3} \mathrm{Me}_{2}-2,6$ (5b), $\mathrm{OC}_{6} \mathrm{H}_{3} \mathrm{Me}_{2}-3,5$ (5c)) show a very strong resemblance with those of the above mentioned complexes containing an intramolecularly coordinating amino group; see Table III. It is well-known that the chemical shift of a carbon atom bonded to the imido nitrogen ${ }^{25}$ or the phenoxide oxygen ${ }^{30}$ is strongly influenced by the electronic properties of the metal atom. Because of the fact that these values for 5 are very similar to those for 1-4, it is likely that in complexes 5a-c the phenoxide ligand is also bonded at an equatorial position and that the coordinating $\mathrm{Et}_{2} \mathrm{O}$ molecule is bonded trans to the phenylimido ligand. The large downfield shift for the $\mathrm{CH}_{2} \mathrm{O}$ hydrogens of the coordinating $\mathrm{Et}_{2} \mathrm{O}$ molecule in $\mathbf{5}$ ( $\Delta \delta=1.0$ for $5 a-c)$ indicates that it is bound to the metal center via a very strong dative bond: it appeared to be impossible to remove the ether molecule in $5 \mathrm{c}$ at $50^{\circ} \mathrm{C}$ in vacuo $\left(10^{-3} \mathrm{mmHg}\right)$.

In order to compare the thermal stabilities of 1 and $2 a$ (containing intramolecular coordination) with that of $\mathbf{5}$, the decomposition temperatures were determined by thermographimetric analysis (TGA). It appeared that 1 and $2 a$ start to decompose at temperatures around $350^{\circ} \mathrm{C}$, whereas $5 \mathrm{~b}$ already decomposes at $150^{\circ} \mathrm{C}$.

\section{Discussion}

The present study shows that a new class of monophenoxide and monoalkoxide tungsten(VI) phenylimido complexes, with

(30) Jackman, L. M.; DeBrosse, C. W. J. Am. Chem. Soc. 1983, 105, 4177.
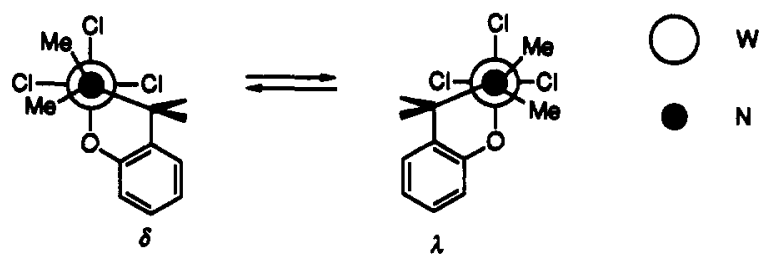

Figure 5. Newman projections along the $N-W$ axis of 1 in which the interconversion between ring conformers, $\delta$ and $\lambda$, in a six-membered chelate ring is represented.

intramolecular $\mathrm{W}-\mathrm{N}$ coordination, is easily accessible. These complexes are monomeric in the solid state (cf. molecular structure of $\mathbf{2 a}$ ), as well as in solution, and are six-coordinate due to intramolecular W-N coordination.

It is well established in early-transition-metal chemistry that alkoxide and phenoxide ligands may occupy either terminal or bridging positions; see Figure 4i.19,31 Likewise, imido ligands can bridge either two and even three metal atoms, ii-iv, while the metal-nitrogen bonds may be symmetric, ii, or asymmetric, iii. ${ }^{32}$ Examples of each type of complexes are $(t-\mathrm{BuO})_{2} \mathrm{~W}(\mu-\mathrm{O}-\mathrm{t}-\mathrm{Bu})_{2-}$ $(\mu-\mathrm{CO}) \mathrm{W}(\mathrm{O}-t-\mathrm{Bu})_{2}{ }^{33}$ or $\left.\mathrm{W}_{2}(\mathrm{CO})_{6}(\mu-\mathrm{OPh})_{3}{ }^{(3-}\right)^{34}$ for i, $\left(\mathrm{Me}_{2} \mathrm{~N}\right)_{2-}$ $\mathrm{Zr}(\mu-\mathrm{N}-t-\mathrm{Bu}) \mathrm{Zr}\left(\mathrm{NMe}_{2}\right)_{2}{ }^{35}$ for ii, [Mo(O-t-Bu $)_{2}(\mathrm{~N}-p$-tolyl $)(\mu-$ $\mathrm{N}$-p-tolyl) $]_{2}{ }^{32}$ for iii, and $\mathrm{Fe}_{3}(\mu-\mathrm{NMe})_{2}(\mathrm{CO})_{9}{ }^{32}$ for iv. The molecular structure of $\left[\mathrm{WCl}_{4}(\mathrm{~N} \text { - } p \text {-tolyl })\right]_{2}$ demonstrates that even the chloride atoms present in a tungsten(VI) imido complex can bridge between two metal centers. ${ }^{36}$

The complexes 1-4, however, all contain intramolecular W-N coordination that obviously is very effective in blocking the sixth coordination site. In 5 this sixth coordination site is occupied by a coordinating diethyl ether molecule. In addition, these phenoxide and alkoxide complexes are all monomeric species, even when imido as well as phenoxide or alkoxide ligands are present.

The influence of intramolecular $\mathrm{W}-\mathrm{N}$ coordination on the properties of these tungsten(VI) phenoxide and alkoxide complexes appears from the high thermal stability, i.e. the absence of intramolecular decomposition pathways (compare: $T_{\mathrm{doc}}$ of $\mathbf{5 b}$ $=150^{\circ} \mathrm{C}$, and $T_{\text {dec }}$ of 1 and $2 \mathrm{a}=350^{\circ} \mathrm{C}$ ).

The strong influence of intramolecular $\mathrm{W}-\mathrm{N}$ coordination was recently also found in a series of aryltungsten(VI) oxo and phenylimido chloride complexes in which a chelating arylamine ligand is present. 10 These complexes also were shown to be thermally very stable, and even at elevated temperatures no $W-N$ dissociation processes were observed. However, in related aryltantalum(V) complexes such intramolecular amine coordination is significantly weaker, and at higher temperature $\mathrm{Ta}-\mathrm{N}$

(31) Chisholm, M.H.; Rothwell, I.P. Comprehensive Coordination Chemistry; Wilkinson, G., Ed.; Pergamon Press: Oxford, U.K., 1987, Vol. 2, Chapter 15.3, p 335 (and references cited therein).

(32) Chisholm, M. H.; Rothwell, I. P. Comprehensive Coordination Chemistry; Wilkinson, G., Ed.; Pergamon Press: Oxford, U.K., 1987; Vol. 2, Chapter 13.4, p 161 (and references cited therein).

(33) Chisholm, M. H.; Hoffman, D. M.; Huffman, J. C. Organometallics 1985, 4, 986.

(34) Darensbourg, D. J.; Sanchez, K. M.; Reibenspies, J. H. Inorg. Chem. $1988,27,3269$

(35) Nugent, W. A.; Harlow, R. L. Inorg. Chem. 1979, 18, 2030.

(36) Clegg, W.; Errington, R. J. Acta Crystallogr. 1987, C34, 2223. 
dissociation occurred, followed by intramolecular aminomethyl $\mathrm{C}-\mathrm{H}$ activation and subsequent formation of an alkane and an intramolecularly bonded tantala(V)azacyclopropane species. ${ }^{20}$

To our knowledge, there is just one other reported example of a tungsten phenoxide complex in which a stabilizing chelating group is present, viz. low-valent tungsten 2,6-diphenylphenoxide complexes, prepared by Rothwell et al., in which one of the orthophenyl substituents forms an $\eta^{6}$-arene bond or can give rise to a $\mathrm{C}-\mathrm{H}$ activation with the subsequent formation of a $\sigma$-aryl bond. $37-42$

Compound $2 \mathrm{a}$ has one strongly bonded ortho- $\mathrm{CH}_{2} \mathrm{NMe}_{2}$ substituent, while the second ortho- $\mathrm{CH}_{2} \mathrm{NMe}_{2}$ substituent is free. It is remarkable that even at elevated temperatures no exchange between these amine substituents occurs. It moreover suggests that six-coordinate tungsten centers are not capable of activating a $\mathrm{C}-\mathrm{H}$ bond in an alkyl group which is held in the coordination sphere of the metal center. Finally, it is surprising that protonation of this free ortho- $\mathrm{CH}_{2} \mathrm{NMe}_{2}$ substituent, as in $2 \mathrm{~b}$, is possible without $\mathrm{W}-\mathrm{O}$ or $\mathrm{W}=\mathrm{N}$ bond cleavage. The inertness of this second amine substituent of the "pincer-phenolate" ligand may lead to interesting reactivities of its metal complexes, since a Lewis base, which is unable to coordinate, is always present in the coordination sphere of the metal center.

\section{Conclusions}

Tungsten(VI) phenylimido monophenoxide and alkoxide complexes containing chelating phenoxide or alkoxide ligands are easily accessible. They are monomeric in the solid state as well as in solution as a result of intramolecular $\mathrm{W}-\mathrm{N}$ coordination. This $\mathbf{W}-\mathbf{N}$ coordination is very strong as $\mathbf{W}-\mathbf{N}$ dissociation processes were not observed, even at elevated temperatures. When a potentially coordinating group is absent within the molecule, coordination of a solvent molecule (diethyl ether in this case) occurs. The complexes containing intramolecular W-N coordination are thermally much more stable than the diethyl ether adducts. The "pincer-phenolate" ligand is bidentate bonded with one free ortho- $\mathrm{CH}_{2} \mathrm{NMe}_{2}$ substituent, and intramolecular exchange between the two amino groups does not occur. The properties of these phenoxide and alkoxide complexes are promising with respect to the planned synthesis of tungsten(VI) alkylidene complexes containing this type of ligands. The strong intramolecular $\mathrm{W}-\mathrm{N}$ coordination may lead to very stable alkylidene complexes having interesting reactivities toward olefins.

\section{Experimental Section}

General Methods. All reactions were carried out in an atmosphere of dry, deoxygenated $\mathrm{N}_{2}$, using standard Schlenk techniques. All solvents were dried and distilled from sodium under nitrogen, prior to use. Commercially available reagents were used as supplied whereas $\mathrm{WCl}_{4}$ $(=\mathrm{NPh})\left(\mathrm{OEt}_{2}\right),{ }^{16} \quad 2-\left\{\left(\right.\right.$ dimethylamino)methyl\}phenol, ${ }^{44}$ and 2,6-bis \{(dimethylamino)methyl\}-4-methylphenol ${ }^{23}$ were synthesized by following literature procedures. $\mathrm{Li}\left(\mathrm{OC}_{6} \mathrm{H}_{4} \mathrm{CH}_{2} \mathrm{NMe}_{2}-2\right)$, and $\mathrm{Li}\left[\mathrm{OC}_{6} \mathrm{H}_{2}\left(\mathrm{CH}_{2}\right.\right.$ $\left.\left.\mathrm{NMe}_{2}\right)_{2}-2,6-\mathrm{Me}-4\right]$ were prepared by reacting the phenols with $n$-BuLi

(37) Chesnut, R. W.; Durfee, L. D.; Fanwick, P. E.; Rothwell, I. P.; Folting, K.; Huffman, J. C. Polyhedron 1987, 6, 2019.

(38) Chesnut, R. W.; Steffey, B. D.; Rothwell, I. P.; Huffman, J.C. Polyhedron $1988,7,753$.

(39) Kerschner, J. L.; Fanwick, P. E.; Rothwell, I. P. J. Am. Chem. Soc. $1987,109,5840$

(40) Kerschner, J. L.; Rothwell, I. P. Organometallics 1988, 7, 1871.

(41) Kerschner, J. L.; Torres, E. M.; Fanwick, P. E.; Rothwell, I. P. Organometallics 1989, 8, 1424

(42) Kerschner, J. L.; Fanwick, P. E.; Rothwell, I. P.; Huffman, J. C. Organometallics 1989, 8, 1431.

(43) Kerschner, J. L.; Yu, J. S.; Fanwick, P. E.; Rothwell, I. P.; Huffman, J. C. Organometallics $1989,8,1414$

(44) (a) Decombe, J. C. R. Seances Acad. Sci. 1933, 196, 866. (b) Böhme, H.; Mundlos, E.; Lehners, W.; Herboth, O-E. Chem. Ber. 1957, 90 , 2008. in a 1:1 ratio in hexane at $-78^{\circ} \mathrm{C} .45 \mathrm{Na} 8$-quinolinolate was prepared from 8-hydroxyquinoline and sodium hydride in THF. Diphenyl-2pyridylmethanol and 2,4-dimethyl-3-(2-pyridyl)pentan-3-ol were prepared via a modified literature procedure ${ }^{46}$ from 2 -pyridyllithium ${ }^{47}$ and the appropriate ketone, followed by hydrolysis. The corresponding lithium alkoxides were prepared as mentioned above for the lithium phenoxides. ${ }^{1} \mathrm{H}$ and ${ }^{13} \mathrm{C}$ NMR spectra were recorded on Bruker AC 200 or AC 300 spectrometers in benzene- $d_{6}$, at room temperature, unless noted otherwise. Thermographimetric analyses were performed on a Perkin-Elmer TGS-2 thermographic system. Cryoscopic measurements were performed in benzene in an inert atmosphere. Elemental analyses were carried out at the Institute for Applied Chemistry TNO, Zeist, The Netherlands, or by the Mikroanalytisches Laboratorium Dornis und Kolbe, Mülheim a.d. Ruhr, Germany.

$\mathrm{WCl}_{3}(=\mathrm{NPh})\left(\mathrm{OC}_{6} \mathrm{H}_{1} \mathrm{CH}_{2} \mathrm{NMe}_{2}-2\right)(1) . \mathrm{Li}\left(\mathrm{OC}_{6} \mathrm{H}_{4} \mathrm{CH}_{2} \mathrm{NMe}_{2}-2\right)(0.51$ $\mathrm{g}, 3.24 \mathrm{mmol}$ ) was added as a solid to a solution of $\mathrm{WCl}_{4}(=\mathrm{NPh})\left(\mathrm{OEt}_{2}\right)$ $(1.59 \mathrm{~g}, 3.24 \mathrm{mmol})$ in $\mathrm{Et}_{2} \mathrm{O}(50 \mathrm{~mL})$ at $0^{\circ} \mathrm{C}$. After the addition was completed, the reaction mixture was warmed to room temperature. This was accompanied by a color change of the reaction mixture from green to brick-red. The reaction mixture was stirred for $3 \mathrm{~h}$, followed by removal of the volatiles in vacuo, and the product was extracted with $\mathrm{CH}_{2} \mathrm{Cl}_{2}$ (40 $\mathrm{mL}$ ) and then dried in vacuo leaving a purple solid, which was washed with pentane $(2 \times 40 \mathrm{~mL})$. The product was dried in vacuo. Yield: 2.98 $g\left(92 \%, T_{\text {dec }}=350^{\circ} \mathrm{C}\right)$. The complex can be crystallized by cooling a toluene solution to $-30^{\circ} \mathrm{C}$. ' $\mathrm{H}$ NMR ( $\left.\delta\right): 7.23-6.60(\mathrm{~m}, 7$, aryl- $\mathrm{H}) ; 6.36$ (t, 1, p-H NPh); 3.60 (br s, 2, $\left.\mathrm{CH}_{2} \mathrm{~N}\right) ; 2.68$ (s, 6, $\left.\mathrm{NMe}_{2}\right) .{ }^{13} \mathrm{C}$ NMR

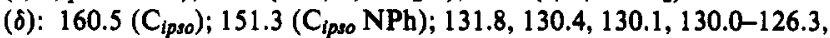
119.1 (aryl-C); $62.8\left(\mathrm{CH}_{2} \mathrm{~N}\right) ; 50.8\left(\mathrm{NMe}_{2}\right)$. Anal. Calcd for $\mathrm{C}_{15} \mathrm{H}_{17} \mathrm{Cl}_{3} \mathrm{~N}_{2} \mathrm{OW}: \mathrm{C}, 33.90 ; \mathrm{H}, 3.22 ; \mathrm{N}, 5.27$. Found: $\mathrm{C}, 33.84 ; \mathrm{H}$, $3.29 ; \mathrm{N}, 5.26$. Molecular weight determination by cryoscopy $(0.21 \mathrm{~g}$ in $20.03 \mathrm{~g}$ of $\mathrm{C}_{6} \mathrm{H}_{6}, 0.018 \mathrm{M}$ ): Calcd, 531.5; found, 515 .

$\mathrm{WCl}_{3}(=\mathrm{NPh})\left[\mathrm{OC}_{6} \mathrm{H}_{2}\left(\mathrm{CH}_{2} \mathrm{NMe}_{2}\right)_{2}-2,6-\mathrm{Me}-4\right]$ (2a). This product was synthesized via a procedure similar to that of 1 . Reaction of $1.42 \mathrm{~g}$ of $\mathrm{Li}\left[\mathrm{OC}_{6} \mathrm{H}_{2}\left(\mathrm{CH}_{2} \mathrm{NMe}_{2}\right)_{2}-2,6-\mathrm{Me}-4\right](6.22 \mathrm{mmol})$ with $\mathrm{WCl}_{4}(=\mathrm{NPh})-$ $\left(\mathrm{OEt}_{2}\right)$ in a $1: 1$ molar ratio afforded $3.49 \mathrm{~g}$ of a dark purple solid $(93 \%$, $T_{\text {dec }}=350^{\circ} \mathrm{C}$ ). The product was crystallized from a saturated benzene solution layered with an equivalent amount of pentane.

Alternative synthesis via alcoholysis: A solution of 2,6-bis [(dimethylamino)methyl]-4-methylphenol ( $1.06 \mathrm{~g}, 4.77 \mathrm{mmol})$ in $\mathrm{Et}_{2} \mathrm{O}(25 \mathrm{~mL})$ was added dropwise to a mixture of $\mathrm{WCl}_{4}(=\mathrm{NPh})\left(\mathrm{OEt}_{2}\right)(2.27 \mathrm{~g}, 4.62$ $\mathrm{mmol}$ ) and $\mathrm{NEt}_{3}(12 \mathrm{mmol})$ in $\mathrm{Et}_{2} \mathrm{O}(50 \mathrm{~mL})$. Upon addition the color of the reaction mixture immediately turned to dark red. After addition, the reaction mixture was stirred for $1 \mathrm{~h}$. The solvent was removed in vacuo leaving a deep purple solid. The reaction product was extracted with $\mathrm{CH}_{2} \mathrm{Cl}_{2}(2 \times 50 \mathrm{~mL})$, and its ${ }^{1} \mathrm{H}$ NMR showed no impurities. Yield: $2.36 \mathrm{~g}(85 \%)$. ${ }^{1} \mathrm{H}$ NMR $(\delta): 7.43(\mathrm{~s}, 1, m-\mathrm{H}) ; 7.31(\mathrm{~d}, 2, o-\mathrm{H} \mathrm{NPh}) ;$ 7.04 (t, 2, m-H NPh); $6.47(\mathrm{t}, 1, p \cdot \mathrm{H} \mathrm{NPh}) ; 6.44(\mathrm{~s}, 1, m-\mathrm{H}) ; 3.61(\mathrm{~s}$, 2, $\mathrm{CH}_{2} \mathrm{NMe}_{2}$-free); 3.6 (br, 2, $\mathrm{CH}_{2} \mathrm{NMe}_{2}$-coord); 2.73 (br s, 6, $\mathrm{CH}_{2} \mathrm{NMe}$ -

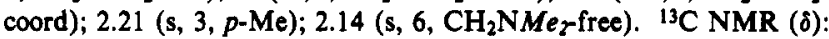
$\left.157.4\left(\mathrm{C}_{\text {ipso }}\right) ; 151.6 \mathrm{C}_{\text {ipso }} \mathrm{NPh}\right) ; 136.4,131.8,131.0,130.2,130.1,129.5-$ 127.1 (aryl-C); 62.8 ( $\mathrm{CH}_{2} \mathrm{~N}$-coord); $57.3\left(\mathrm{CH}_{2} \mathrm{~N}\right.$-free); 50.8 ( $\mathrm{NMe}_{2}-$ coord); 45.9 (NMer-free); 20.9 (p-Me). Anal. Calcd for $\mathrm{C}_{19} \mathrm{H}_{26} \mathrm{Cl}_{3} \mathrm{~N}_{3} \mathrm{OW}: \mathrm{C}, 37.87 ; \mathrm{H}, 4.35 ; \mathrm{N}, 6.97$. Found: $\mathrm{C}, 37.61 ; \mathrm{H}$, $4.25 ; \mathrm{N}, 6.97$. Molecular weight determination by cryoscopy $(0.27 \mathrm{~g}$ in $18.60 \mathrm{~g}$ of $\mathrm{C}_{6} \mathrm{H}_{6}, 0.021 \mathrm{M}$ ): Calcd, 602.7 ; found, 618 .

$\mathrm{WCl}_{3}(=\mathrm{NPh})\left[\mathrm{OC}_{6} \mathrm{H}_{2}\left(\mathrm{CH}_{2} \mathrm{NMe}_{2}-2\right)(\mathrm{Me}-4)\left(\mathrm{CH}_{2} \mathrm{NHMe}_{2} \mathrm{Cl}-6\right)\right]$ (2b). This complex was prepared via the alcoholysis reaction described above for 2a. However, the alcoholysis was carried out in the absence of $\mathrm{NEt}_{3}$. Complex $2 b$ was also prepared by a titration of a solution $2 \mathrm{a}$ in $\mathrm{Et}_{2} \mathrm{O}$ with a $1.8 \mathrm{M} \mathrm{HCl}$ solution in $\mathrm{Et}_{2} \mathrm{O}$. Both reactions gave $2 \mathrm{~b}$ as a red solid

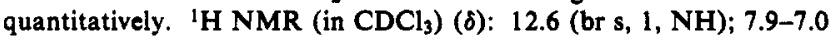
(m, 7, Ar-H); 4.21 (d, 2, $\left.\mathrm{CH}_{2} \mathrm{NHMe}_{2}\right) ; 4.11$ (s, 2, $\left.\mathrm{CH}_{2} \mathrm{NMe}_{2}\right) ; 2.96(\mathrm{~s}$, 6, $\left.\mathrm{CH}_{2} \mathrm{NMe}_{2}\right) ; 2.72\left(\mathrm{~d}, 6, \mathrm{CH}_{2} \mathrm{NHMe}\right.$ ); $2.50(\mathrm{~s}, 3, \mathrm{p}-\mathrm{Me})$. Anal. Calcd for $\mathrm{C}_{19} \mathrm{H}_{27} \mathrm{Cl}_{4} \mathrm{~N}_{3} \mathrm{OW}$ : $\mathrm{C}, 35.71 ; \mathrm{H}, 4.26 ; \mathrm{N}, 6.57$. Found: $\mathrm{C}, 35.47 ; \mathrm{H}$, $4.62 ; \mathrm{N}, 6.35$

$\mathrm{WCl}_{3}(-\mathrm{NPh}$ )(8-quinolinolate) (3). This product was prepared from $\mathrm{WCl}_{4}(=\mathrm{NPh})\left(\mathrm{OEt}_{2}\right)(4.82 \mathrm{~g}, 9.83 \mathrm{mmol})$ and $\mathrm{Na}$ 8-quinolinolate $(1.65$ $\mathrm{g}, 9.87 \mathrm{mmol}$ ) by a procedure ( $12 \mathrm{~h}$ of stirring) similar to that described a bove for 1 . Crystalline, deep-purple 3 was obtained by cooling a saturated

(45) Van der Schaaf, P. A.; Jastrzebski, J. T. B. H.; Hogerheide, M. P.; Smeets, W. J. J.; Spek, A. L.; Boersma, J.; Van Koten, G. Inorg. Chem. $1993,32,4111$.

(46) Wibaut, J. P. De Jonge, A. P.; Van der Voort, H. G. P.; Otto, P. Ph. H. L. Recl. Trav. Chim. Pays-Bas 1951, 70, 1054.

(47) (a) Gilman, H.; Spatz, S. M. J. Am. Chem. Soc. 1940, 62, 446. (b) Malmberg, H.; Nilsson, M. Tetrahedron 1982, 38, 1509. 
$\mathrm{CH}_{2} \mathrm{Cl}_{2}$ solution to $-30^{\circ} \mathrm{C}$. Yield: $4.81 \mathrm{~g}(87 \%)$. ${ }^{1} \mathrm{H}$ NMR (in $\mathrm{CDCl}_{3}$ )

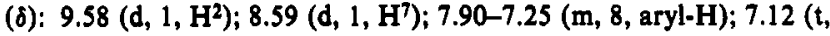
$1, p-H ~ N P h)$. ${ }^{13} \mathrm{C}$ NMR $(\delta): 158.6\left(C_{i p s o}\right.$ OAr $) ; 149.9\left(C_{\text {ipso }} \mathrm{NPh}\right)$; 140.1, 140.0, 132.2, 130.5, 129.6, 129.2, 127.6, 124.6, 123.6118 .4 (arylC). Anal. Caled for $\mathrm{C}_{15} \mathrm{H}_{11} \mathrm{Cl}_{3} \mathrm{~N}_{2} \mathrm{OW}$ : C, 34.29; $\mathrm{H}, 2.11 ; \mathrm{N}, 5.33$. Found: C, 34.34; H, 2.19; N, 5.26.

$\mathrm{WCl}_{3}(-\mathrm{NPh})\left[\mathrm{OC}-\mathrm{Pr}_{2}(2-\mathrm{Py})\right](4 a)$. This complex was prepared via a procedure similar to the one given for 1 . Reaction of $\mathrm{Li}\left[\mathrm{OC}-i-\mathrm{Pr}_{2-}\right.$ (2-Py)] $(3.21 \mathrm{~g}, 16.11 \mathrm{mmol})$ with 1 equiv of $\mathrm{WCl}_{4}(=\mathrm{NPh})\left(\mathrm{OEt}_{2}\right)$ in $\mathrm{Et}_{2} \mathrm{O}(80 \mathrm{~mL})$ yields $8.31 \mathrm{~g}$ of $4 \mathrm{a}$ as a red solid $(90 \%)$. ' $\mathrm{H}$ NMR $(\delta)$ : $\left.9.56\left(\mathrm{~d}, 1, \mathrm{H}^{6}\right) ; 7.28(\mathrm{~d}, 2), 6.99 \mathrm{M}, 3\right), 6.68(\mathrm{~d}, 1), 6.55(\mathrm{t}, 1)$ (aryl-H); $6.48(\mathrm{t}, 1, \mathrm{p}-\mathrm{H} \mathrm{NPh}) ; 2.27$ (dq, 2, $-\mathrm{CHMe}$ ); 0.99, 0.97 (2d, 12,-CHMe $)$. ${ }^{13} \mathrm{C}$ NMR $(\delta)$ : 168.3 (C ipso Py); 151.5 (C $\left.C_{\text {ipso }} \mathrm{NPh}\right) ; 149.4,139.8,131.1$, $129.9,124.7,121.3$ (aryl-C); 105.3 (CO); $36.5\left(-\mathrm{CHMe}_{2}\right) ; 20.1,17.8$ $\left(-\mathrm{CHMe} e_{2}\right)$. Anal. Calcd for $\mathrm{C}_{18} \mathrm{H}_{23} \mathrm{Cl}_{3} \mathrm{~N}_{2} \mathrm{OW} \cdot 0.5 \mathrm{C}_{6} \mathrm{H}_{6}: \mathrm{C}, 41.17 ; \mathrm{H}$, 4.28; N, 4.57. Found: $C, 40.98 ; \mathrm{H}, 4.24 ; \mathrm{N}, 5.53$. Molecular weight determination by cryoscopy $\left(0.14 \mathrm{~g}\right.$ in $16.45 \mathrm{~g}$ of $\left.\mathrm{C}_{6} \mathrm{H}_{6}, 0.013 \mathrm{M}\right)$ : Calcd, 573.6; found, 565.

$\mathrm{WCH}_{3}(=\mathrm{NPh})(\mathbf{O C P h}$ (2-Py)\} (4b). This complex was prepared in THF (reflux, $3 \mathrm{~h}$ ), using the workup procedure described for 1 . Starting with $\mathrm{Li}\left[\mathrm{OCPh}_{2}(2-\mathrm{Py})\right](1.23 \mathrm{~g}, 4.60 \mathrm{mmol})$ yields $2.54 \mathrm{~g}$ of $4 \mathrm{~b}$ as a red solid (86\%). ' ${ }^{2} \mathrm{HNMR}(\delta): 9.51$ (d, $\left.1, \mathrm{H}^{6} \mathrm{Py}\right) ; 7.36-6.82$ (m, 16, aryl-H); 6.56 $\left(\mathrm{t}, 1, \mathrm{H}^{3} \mathrm{Py}\right) ; 6.44(\mathrm{t}, 1, p-\mathrm{H} \mathrm{NPh}),{ }^{13} \mathrm{C}$ NMR $(\delta): 164.7$ (C $\left.\mathrm{C}_{\text {ipso }} \mathrm{Py}\right) ; 151.2$ $\left(C_{\text {ipso }} \mathrm{NPh}\right) ; 148.8,142.5,139.5,131.3,129.9,129.0,128.9,128.9,127.7$, 125.1 (aryl-C); $103.7(\mathrm{CO})$. Anal. Calod for $\mathrm{C}_{24} \mathrm{H}_{19} \mathrm{Cl}_{3} \mathrm{~N}_{2} \mathrm{OW}$ : C, 44.93; $\mathrm{H}, 2.98 ; \mathrm{N}, 4.37$. Found: $\mathrm{C}, 45,00 ; \mathrm{H}, 3.06 ; \mathrm{N}, 4.43$.

Synthesis of the Methyl-Substituted Phenoxide Tungsten(VI) Phenylimido Chlorides. One equivalent of 4-methyl-, 2,6-dimethyl-, or 3,5dimethylphenol was added as a solid to a solution of $\mathrm{WCl}_{4}(-\mathrm{NPh})\left(\mathrm{OEt}_{2}\right)$ $(10 \mathrm{mmol})$ in $\mathrm{Et}_{2} \mathrm{O}(60 \mathrm{~mL})$ over a period of $15 \mathrm{~min}$. During the reaction the reaction flask was flushed with a flow of $\mathrm{N}_{2}$. When the evolution of $\mathrm{HCl}$ had ceased (generally after $2 \mathrm{~h}$ ), the crude reaction mixture was concentrated to $10 \mathrm{~mL}$ in vacuo and then cooled to $0^{\circ} \mathrm{C}$. The product was separated from the $\mathrm{Et}_{2} \mathrm{O}$ layer by centrifugation and dried in vacuo. The isolated yields of the products, which are moisture-sensitive, deeppurple solids, are generally between 85 and $95 \%$.

$\mathrm{WCl}_{3}(=\mathrm{NPh})\left(\mathrm{OC}_{\mathrm{d}} \mathrm{HMe}_{4} \mathrm{M}\right)\left(\mathrm{OEt}_{2}\right)(5 \mathrm{a})$. ${ }^{1} \mathrm{H}$ NMR $(\delta): 7.03-6.79$ $\left(\mathrm{m}, 8\right.$, aryl-H); $6.38(\mathrm{t}, 1, p-\mathrm{H} \mathrm{NPh}) ; 4.31\left(\mathrm{q}, 4, \mathrm{OCH} \mathrm{CH}_{3}\right), 2.08$ (s, 3,

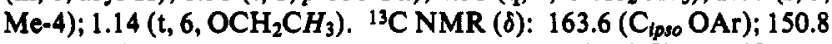
$\left(\mathrm{C}_{\text {lpos }} \mathrm{NPh}\right) ; 136.1,132.0,130.0,129.9,127.7,118.1$ (aryl-C); 66.2 $\left(\mathrm{OCH}_{2-}\right.$ $\left.\mathrm{CH}_{3}\right) ; 20.6(\mathrm{Me}-4) ; 13.3\left(\mathrm{OCH}_{2} \mathrm{CH}_{3}\right)$. Anal. Calcd for $\mathrm{C}_{17} \mathrm{H}_{22} \mathrm{Cl}_{3-}$ $\mathrm{NO}_{2} \mathrm{~W}: \mathrm{C}, 36.29 ; \mathrm{H}, 3.94 ; \mathrm{N}, 2.49$. Found: $\mathrm{C}, 36.18 ; \mathrm{H}, 3.88 ; \mathrm{N}, 2.54$.

$\mathrm{WCl}_{3}(=\mathrm{NPh})\left(\mathrm{OC}_{\mathbf{d}} \mathrm{H}_{4} \mathrm{Met}_{2}-2,6\right)\left(\mathrm{OEt}_{2}\right)(5 \mathrm{~b}) . \mathrm{T}_{\mathrm{dec}}=150^{\circ} \mathrm{C}$. ' $\mathrm{H} \mathrm{NMR}$ (o): 6.96-6.82 (m, 6, aryl-H); $6.69(\mathrm{t}, 1, p-\mathrm{H}$ OAr $) ; 6.36(\mathrm{t}, 1, p-\mathrm{H} \mathrm{NPh})$; $4.27\left(\mathrm{q}, 4, \mathrm{OCH}_{2} \mathrm{CH}_{3}\right) ; 2.52(\mathrm{~s}, 6, \mathrm{Me}-2,6) ; 1.12\left(\mathrm{t}, 4, \mathrm{OCH}_{2} \mathrm{CH}_{3} .{ }^{13} \mathrm{C}\right.$ NMR $(\delta) ; 163.7\left(C_{i p s o}\right.$ OAr); $151.1\left(C_{i p s o} \mathrm{NPh}\right) ; 136.0,132.0,129.7$, $129.3,127.7,125.9$ (aryl-C); $65.7\left(\mathrm{OCH}_{2} \mathrm{CH}_{3}\right) ; 17.9(\mathrm{Me}-2,6) ; 13.3$ $\left(\mathrm{OCH}_{2} \mathrm{CH}_{3}\right)$. Anal. Calcd for $\mathrm{C}_{18} \mathrm{H}_{24} \mathrm{Cl}_{3} \mathrm{NO}_{2} \mathrm{~W}: \mathrm{C}, 37.50 ; \mathrm{H}, 4.20 ; \mathrm{N}$, 2.43. Found: C, 37.42; $\mathrm{H}, 4.30 ; \mathrm{N}, 2.47$.

$\mathrm{WCl}_{3}(=\mathrm{NPh})\left(\mathrm{OC}_{6} \mathrm{H}_{4} \mathrm{Me}_{2}-3,5\right)\left(\mathrm{OEt}_{2}\right)(\mathrm{Sc}) .{ }^{1} \mathrm{H} \mathrm{NMR}(\delta): 7.01-6.8$ (m, 6, aryl-H); $6.45(\mathrm{~s}, 1, \mathrm{p}-\mathrm{H}$ OAr); $6.36(\mathrm{t}, 1, p-\mathrm{H} \mathrm{NPh}) ; 4.33$ (q, 4 , $\left.\mathrm{OCH}_{2} \mathrm{CH}_{3}\right), 1.92(\mathrm{~s}, 6, \mathrm{Me}-2,6) ; 1.16\left(\mathrm{t}, 4, \mathrm{OCH}_{2} \mathrm{CH}_{3}\right) .{ }^{13} \mathrm{C} \mathrm{NMR}(\delta)$ : 165.6 ( $\left.\mathrm{C}_{\text {ipso }} \mathrm{OAr}\right) ; 150.8\left(\mathrm{C}_{\text {lpsso }} \mathrm{NPh}\right) ; 139.4,131.9,130.0,128.3,116.0$ (aryl-C); $66.2\left(\mathrm{OCH}_{2} \mathrm{CH}_{3}\right) ; 21.1(\mathrm{Me}-3,5) ; 13.3\left(\mathrm{OCH}_{2} \mathrm{CH}_{3}\right)$. Anal. Calod for $\mathrm{C}_{18} \mathrm{H}_{24} \mathrm{Cl}_{3} \mathrm{NO}_{2} \mathrm{~W}$ : C, 37.50; $\mathrm{H}, 4.20 ; \mathrm{N}, 2.43$. Found: $\mathrm{C}$, 37.36; H, 4.22; N, 2.49.

X-ray Structure Determination and Refinement of Complex 2a. A dark-red block-shaped crystal was glued on top of a glass fiber and transferred to an Enraf-Nonius CAD4T diffractometer (rotating anode, $50 \mathrm{kV}, 200 \mathrm{~mA}$, graphite-monochromated Mo K $\alpha$ radiation) for data
Table IV. Crystal Data and Details of the Structure Determination of Complex 2a

\begin{tabular}{ll}
\hline formula & $\mathrm{WC}_{19} \mathrm{H}_{26} \mathrm{Cl}_{3} \mathrm{~N}_{3} \mathrm{O}$ \\
mol wt & 602.64 \\
space group & $P 2_{1} / c(\mathrm{No} .14)$ \\
$a-c, \AA$ & $6.893(1), 15.415(2), 21.334(2)$ \\
$\beta$, deg & $94.53(1)$ \\
$V, \AA^{3}$ & $2259.7(5)$ \\
$Z$ & 4 \\
$D_{\text {calc, }} \mathrm{g} \mathrm{cm}^{-3}$ & 1.772 \\
$\mu, \mathrm{cm}^{-1}$ & 55.9 \\
radiation $(\lambda, \AA)$ & $\mathrm{Mo} \mathrm{K \alpha}(\mathrm{graphite-monochromated)}$ \\
& $(0.71073)$ \\
final $R$, and $R_{\mathrm{w}}, S$ & $0.0353,0.0259,1.96$ \\
min, max resd dens, $\mathrm{e} / \AA^{3}$ & $-0.84,0.71$ (near W)
\end{tabular}

collection. Unit-cell parameters were determined from a least-squares treatment of the SET4 settings angles of 25 reflections with $11.3<\theta<$ $14.2^{\circ}$. Unit-cell parameters were checked for the presence of higher lattice symmetry.48 Data were corrected for $L_{p}$ and for absorption (DIFABS;49 correction range $0.818-1.216$ ) and for linear decay (61\%) observed in the intensity control reflections during the $36 \mathrm{~h}$ of X-ray exposure time. The structure was solved with direct methods (SHELXS86) ${ }^{50}$ and subsequent difference Fourier analyses. Refinement on $F$ was carried out by full-matrix least-squares techniques. H-atoms were introduced at calculated positions $(\mathrm{C}-\mathrm{H}=0.98 \mathrm{~A}$ ) and included in the refinement riding on their carrier atoms. All non- $\mathrm{H}$ atoms were refined with anisotropic thermal parameters, and $\mathrm{H}$-atoms with one common isotropic thermal parameter $\left(U=0.071(3) \AA^{2}\right)$. Weights were introduced in the final refinement cycles; convergence was reached at $R$ $=0.0353$ and $R_{w}=0.0259$, with $w=1 /\left[\sigma^{2}(F)\right]$. Crystal data and the numerical details of the structure determination are given in Table IV. Final atomic coordinates and the equivalent thermal parameters are listed in Table I. Neutral-atom scattering factors were taken from Cromer and $\mathrm{Mann}^{51}$ and corrected for anomalous dispersion. ${ }^{32}$ All calculations were performed with SHELX76 $6^{53}$ and PLATON ${ }^{54}$ (geometrical calculations and illustrations) on a DEC 5000 system.

Acknowledgment. This work was supported in part (P.A.v.d.S., W.J.J.S., and A.L.S.) by the Netherlands Foundation for Chemical Research (SON) with financial aid from the Netherlands Organization for Advancement of Pure Research (NWO). We thank Mr. E. J. Vlietstra for performing the TGA measurements and Mr. R. A. T. M. Abbenhuis for experimental assistance.

Supplementary Material Available: Tables of anisotropic thermal parameters, all $\mathrm{H}$ atoms parameters, bond lengths and angles, and crystallographic details for 2 a ( 5 pages). Ordering information is given on any current masthead page.

(48) Spek, A. L. J. Appl. Crystallogr. 1988, 21, 578.

(49) Walker, N.; Stuart, D. Acta Crystallogr. A 1983, 39, 158.

(50) Sheldrick, G. M. SHELXS86. Program for crystal structure determination; University of Gottingen: Gơttingen, Federal Republic of Germany, 1986.

(51) Cromer, D. T.; Mann, J. B. Acta Crystallogr. A 1968, 24, 321.

(52) Cromer, D. T.; Liberman, D. J. Chem. Phys. 1970, 53, 1891.

(53) Sheldrick, G. M. SHELX76. Crystal structure analysis package; University of Cambridge: Cambridge, England, 1976.

(54) Spek, A. L. Acta Crystallogr. A 1990, 46, C34. 